\title{
The genus Jeekelosoma Mauriès, 1985 - Moroccan cave millipedes (Diplopoda, Polydesmida, Paradoxosomatidae)
}

\author{
Henrik ENGHOFF $^{1, *}$ \& Ana Sofia P.S. REBOLEIRA ${ }^{2}$ \\ ${ }^{1,2}$ Natural History Museum of Denmark, University of Copenhagen, Universitetsparken 15, \\ DK-2100 København Ø, Denmark. \\ *Corresponding author: henghoff@snm.ku.dk \\ 2Email: sreboleira@snm.ku.dk \\ ${ }^{1}$ urn:lsid:zoobank.org:author:FB09A817-000D-43C3-BCC4-2BC1E5373635 \\ ${ }^{2}$ urn:1sid:zoobank.org:author:338DE845-4839-4EF5-B684-587C021F076C
}

\begin{abstract}
Jeekelosoma Mauriès, 1985, is upgraded from subgenus status under Eviulisoma Silvestri, 1910 to full genus status. The type species, Jeekelosoma abadi (Mauriès, 1985) is redescribed based on topotypical material from a cave in Morocco. Jeekelosoma heptarachne sp. nov. and J. viginti sp. nov. are described from two further Moroccan caves.
\end{abstract}

Keywords: Taxonomy, Eviulisoma, troglobiont, caves, North Africa.

Enghoff H. \& Reboleira A.S.P.S. 2019. The genus Jeekelosoma Mauriès, 1985 - Moroccan cave millipedes (Diplopoda, Polydesmida, Paradoxosomatidae). European Journal of Taxonomy 523: 1-16.

https://doi.org/10.5852/ejt.2019.523

\section{Introduction}

The subterranean fauna of millipedes in the Mediterranean region is extremely rich, and without doubt numerous new species remain to be discovered, in caves as well as in other subterranean habitats such as the mesovoid shallow stratum (MSS). Some of the subterranean millipedes from this region are taxonomically isolated from epigean forms from the same area, the most prominent example of this being Cantabrodesmus lorioli Mauriès, 1971, originally assigned to the American-Indo-Australian family Platyrhacidae (Mauriès 1971, 1974), but subsequently classified in the Afrotropical subfamily Prepodesmine of family Chelodesmidae (Hoffman 1980; Enghoff et al. 2015; see also Luque \& Labrada 2017). Also, the species described from a cave in Morocco as Eviulisoma (Jeekelosoma) abadi by Mauriès (1985) is remarkable since the numerous other species of the genus Eviulisoma Silvestri, 1910 all occur in the Afrotropical region (Jeekel 2003; VandenSpiegel \& Golovatch 2014; Enghoff 2018; Nzoko Fiemapong et al. 2018). Prompted by the availability of topotypical material of E. (J.) abadi and two new congeneric species from other Moroccan caves we here analyse the status of the taxon Jeekelosoma, which we upgrade to full genus status, describe the two new species and provide descriptive notes on $J$. abadi comb. nov. 
Mauriès (1985) justified his new subgenus by three attributes of $J$. abadi:

1. the geographical (Morocco vs Afrotropical) and ecological (cave inhabitant vs epigean) isolation

2. the shape of the gonopod aperture, almost divided medially by a narrow vertical lamella

3. the solenomere which he regarded as being independent [from the rest of the acropodite] from a more basal level than in Eviulisoma s. str.

The first of these criteria is invalid: distribution and habitat choice are not laid down in the genotype of a taxon. The third criterion is also invalid: the solenomere of all the species of Eviulisoma studied by Enghoff (2018), as well as of all those in which the character can be evaluated from the literature, is independent from the rest of the acropodite at an equally basal level as it is in J. abadi. The second criterion, however, seems indeed to set J. abadi aside vis-à-vis the other species. Jeekelosoma abadi also differs from species of Eviulisoma in certain other characters (cf. Enghoff 2018), which are shared by the new species described here:

- three rows of metazonital setae (vs one row in Eviulisoma)

- metazonital setae borne on tubercles (vs no tubercles in Eviulisoma)

- ozopores borne on differently shaped outgrowths/strongly modified peritremata (vs flush with surface in Eviulisoma)

Jeekel (2003) tentatively regarded Jeekelosoma as a full genus: "Indeed a consideration of this species, Eviulisoma abadi Mauriès, 1958 [sic], leads to the conclusion that this species without difficulty deserves generic treatment of its own". Based on the abovementioned differences, Jeekel's suggestion seems warranted, and we herewith formalize the upgrading of Jeekelosoma to a full genus.

\section{Material and methods}

Specimens were obtained from the collection of the Zoological Museum of Barcelona (MZB) where the holotypes and additional material will be deposited except for some duplicates which will be transferred to the Natural History Museum of Denmark (NHMD).

Specimens were examined under a binocular stereo microscope Leica M165C, and measurements were made with the software Leica Application Suite V4.12. The gonopods were dissected and mounted on temporary slides in lactic acid or glycerine for study under light microscopy in a Leica DM2500 microscope. Images of the gonopods were stacked with the software Zerene Stacker. For scanning electron microscopy (SEM) specimens were mounted on aluminium stubs, coated for 110 seconds with platinum/palladium, and studied in a JEOL JSM-6335F microscope. The background of some SEM images was processed with Adobe Photoshop CS6.

\section{Results}

Class Diplopoda de Blainville in Gervais, 1844

Order Polydesmida Leach, 1815

Family Paradoxosomatidae Daday, 1889

Subfamily Paradoxosomatinae Daday, 1889

Tribe Eviulisomatini Brölemann, 1916

Genus Jeekelosoma Mauriès, 1985 stat. nov.

Jeekelosoma Mauriès, 1985: 52, as subgenus of Eviulisoma Silvestri, 1910, type species: Eviulisoma (Jeekelosoma) abadi Mauriès, 1985. 


\section{Diagnosis}

A genus of small, depigmented species (Fig. 1) of the tribe Eviulisomatini sensu Enghoff (2018). Differs from contribal genera by the strongly modified peritremata bearing the ozopores and by the horizontal or oblique row of denticles on each side of each podous body ring. Further differs from contribal genera except Boreviulisoma Brolemann, 1928, by having three transverse rows of setae on postcollar rings.

\section{Included species:}

Jeekelosoma abadi (Mauriès, 1985) comb. nov.

Jeekelosoma heptarachne sp. nov.

Jeekelosoma viginti sp. nov.

\section{Distribution}

Morocco, in caves.

\section{Key to the species of Jeekelosoma}

1. Adults with 20 'segments' ( 17 podous rings +1 apodous ring + telson) J. viginti sp. nov.

- Adults with 19 'segments' (16 podous rings +1 apodous ring + telson)

2. Peritremata ovoid, mushroomlike (Fig. 2G), leg femora shorter than body height, gonopod solenophore with a curved terminal appendage (Fig. 4) J. abadi (Mauriès, 1985) comb. nov.

- Peritremata cylindrical (Fig. 6G-H), leg femora longer than body height, gonopod solenophore without a terminal appendage (Figs 7-8) J. heptarachne sp. nov.

Jeekelosoma abadi (Mauriès, 1985) comb. nov.

Figs 1-4

Eviulisoma (Jeekelosoma) abadi Mauriès, 1985: 52, figs 1-13.

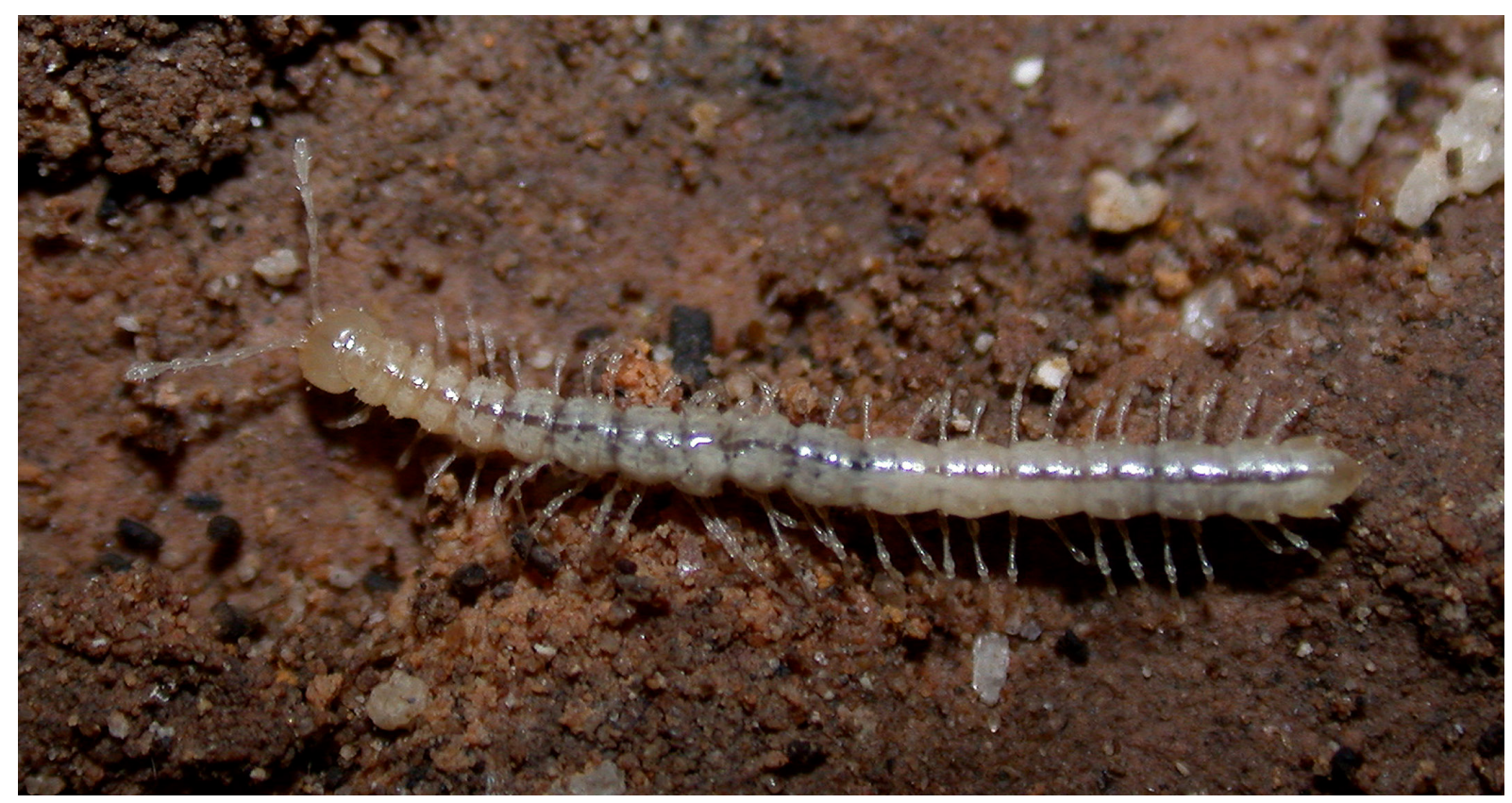

Fig. 1. Jeekelosoma abadi (Mauriès, 1985) comb. nov., living specimen from the type locality. Courtesy of Carles Hernando. 


\section{Diagnosis}

A species of Jeekelosoma with 17 podous rings, with the ozopores borne on mushroomlike peritremata each provided with one macroseta, with a horizontal row of tubercles on podous rings 5-17, and with a terminal curved appendage on the gonopod solenophore.

\section{Material examined}

MOROCCO $・ 2 \precsim \hat{\jmath}, 5$ 우, 1 subad. + TOPOTYPES; Tazouguert, Boudenib, cave Kef Aziza; 31 May 2001; O. Escola leg.; MZB 2003-1386, MZB 2019-0014, MZB 2019-0015, MZB 2019-0016, MZB 2019-0017, MZB 2019-0018, MZB 2019-0019 • 2 ふぇ,, 2 우우; same collecting data; NHMD 302019, NHMD 302020, NHMD 302021, NHMD 302022.

\section{Descriptive notes}

Based on studied specimens, to supplement original description (Mauriès 1985) and to introduce gonopod terminology of Enghoff (2018).

\section{Male}

SizE. Body length 10-11 mm, max. width $0.67 \mathrm{~mm}, 19$ 'segments' (17 podous rings +1 apodous ring + telson).

MidBody Rings (Fig. 2D, F). Elongated, length of metazona equaling ca $3 / 4$ of maximum width. Body extremely narrow in anterior part, maximum width attained a little behind midbody. From there until and including ring 18 (the apodous ring in front of telson) body parallel-sided. Surface of metazona with very pronounced microcellulate structure, borders between cuticular scutes raised. Metazona with diameter increasing towards rear margin and with a clear constriction ca at the middle; posterior margin of rings finely crenulate but without a proper limbus. Each metazona with three rows of short setae borne on distinct tubercles; each row on midbody rings with ca 6 setae; intermediate row situated just behind constriction. A longitudinal row of tubercles on each side of metazona, consisting of a series of ca 5 tubercles in front of constriction plus, in ozopore-less rings, an additional series of ca 5 tubercles behind constriction. Posteriormost tubercles in each row with setae similar to those in transverse rows.

OzOPOREs (Fig. 2G). On peculiar mushroomlike outgrowths (modified peritremata); each 'mushroom' with one long seta behind pore and several minute setae scattered over the surface; outline of 'mushrooms' almost circular on anterior part of body, more oval towards the rear.

STERNA. Unmodified, no process on sternum 5, no excavation on sternum 6.

LeGs (Figs 2E; 3C-D). Slender, but femora considerably shorter than body diameter; femora distally swollen. No scopulae.

Telson (Fig. 3A-B). Preanal ring triangular in dorsal view, lateral tubercles indicated by 'steps' shortly before the subrectangular tip (epiproct); two transverse rows of setae plus several marginal setae. Anal valves (paraprocts) with raised mesal margin ('lips'), each with two setae, the ventral one situated slightly closer to the mesal margin than the dorsal one. Subanal scale (hypoproct) trapezoid, with two long marginal setae.

GonOpodal APERTURE (Fig. 4A-B, E). Figure 8-shaped, almost complete divided in midline by vertical, compressed lobe arising from posterior margin of aperture.

Gonopods (Fig. 4). Coxa (not visible in Fig. 4, but see Mauriès 1985: fig. 13) simple, without a distomedial lobe); prefemoral part (prf) less than half as long as acropodite; mesal acropodital process 

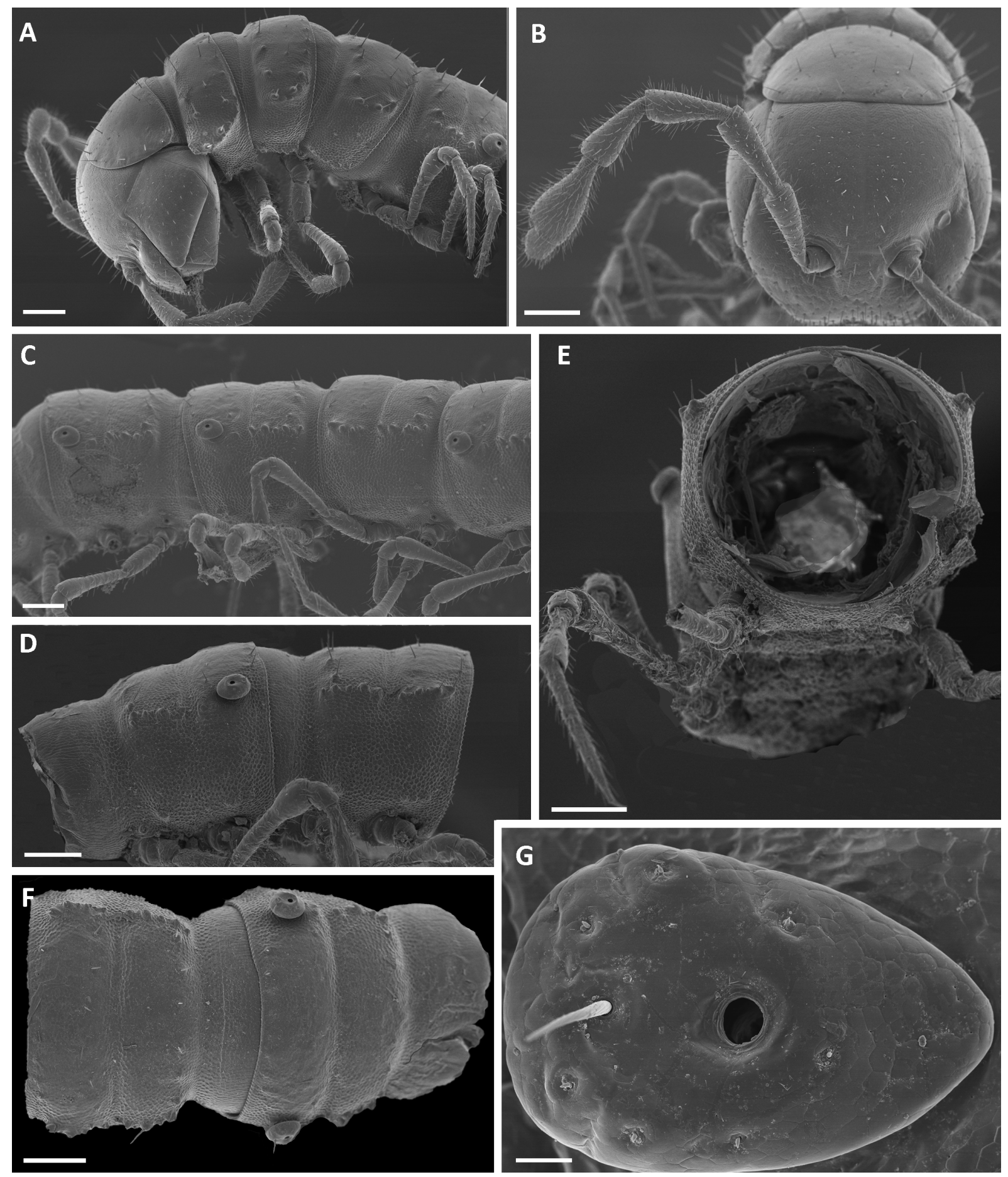

Fig. 2. Jeekelosoma abadi (Mauriès, 1985) comb. nov., topotypes. A-C. Female (NHMD 302022). D-G. Male (NHMD 302021). A. Head and body rings 1-5, lateral view. B. Head and collum, frontal view. C. Body rings $8-10$ and posterior half of ring 7, seen from the right. D. Rings 10-11, seen from the left. E. Ring 11 and legs, posterior view. F. Rings 10-11, dorsal view. G. Ozopore from ring 18, right side (anterior to the right). Scale bars: A-F $=0.2 \mathrm{~mm} ; \mathrm{G}=0.02 \mathrm{~mm}$. 
(map, "T" of Mauriès 1985) a simple broad, dorso-ventrally flattened lobe; solenophore (sph, "S" of Mauriès 1985) as long as map, slender, apically dividing into a subrectangular lamella (sph-a) with distal corners drawn out into long processes, and a terminal slender appendage (app) making a U-turn resulting in its rugose tip pointed towards gonopod base; solenomere $(\mathrm{slm})$ slender, simple, largely concealed within sph.

\section{Female}

SizE. Body length $12 \mathrm{~mm}$, max. width $0.83 \mathrm{~mm}$.

\section{Distribution and habitat}

Known only from the type locality, the Kef Aziza cave, situated at $03^{\circ} 47^{\prime} 17^{\prime \prime}$ W, $32^{\circ} 01^{\prime} 46^{\prime \prime} \mathrm{N}$, near Tazzouguert (http://www.openspeleo.org/openspeleo/caves-view-294.html). This cave is also home to other cave-adapted species including the aquatic isopod Magniezia gardei Magniez, 1977, the palpigrade Eukoenenia maroccana Barranco \& Mayoral, 2008, the spider Dysdera caeca Ribera, 1993, the ground beetle Platyderus insignitus presahariensis Lagar, 1978, the rove beetle Apteranillus ruei Español, 1969, the darkling beetle Scaurus tingitanus gimeli Antoine, 1953, and the weevil Torneuma troglodytis Stüben, 2009 (Antoine 1953; Español 1969; Magniez 1977; Lagar 1978; Ribera 1993; Barranco \& Mayoral 2008; Stüben 2009).
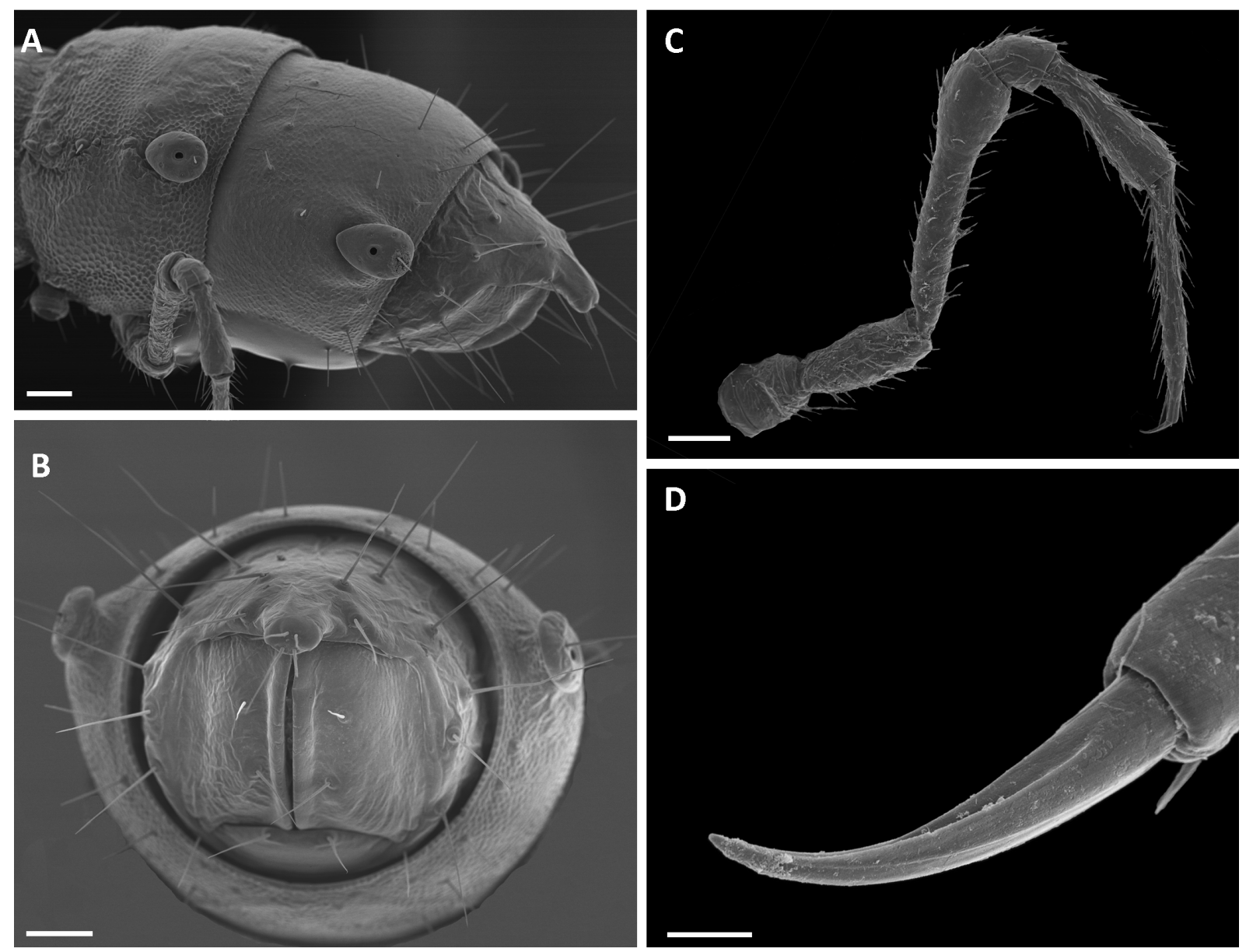

Fig. 3. Jeekelosoma abadi (Mauriès, 1985) comb. nov., male topotype (NHMD 302021). A. Penultimate ring (podous), ultimate ring (apodous) and telson, oblique lateral view. B. Telson, posterior view. C. Midbody leg. D. Claw of midbody leg. Scale bars: A-C = $0.1 \mathrm{~mm} ; \mathrm{D}=0.01 \mathrm{~mm}$. 


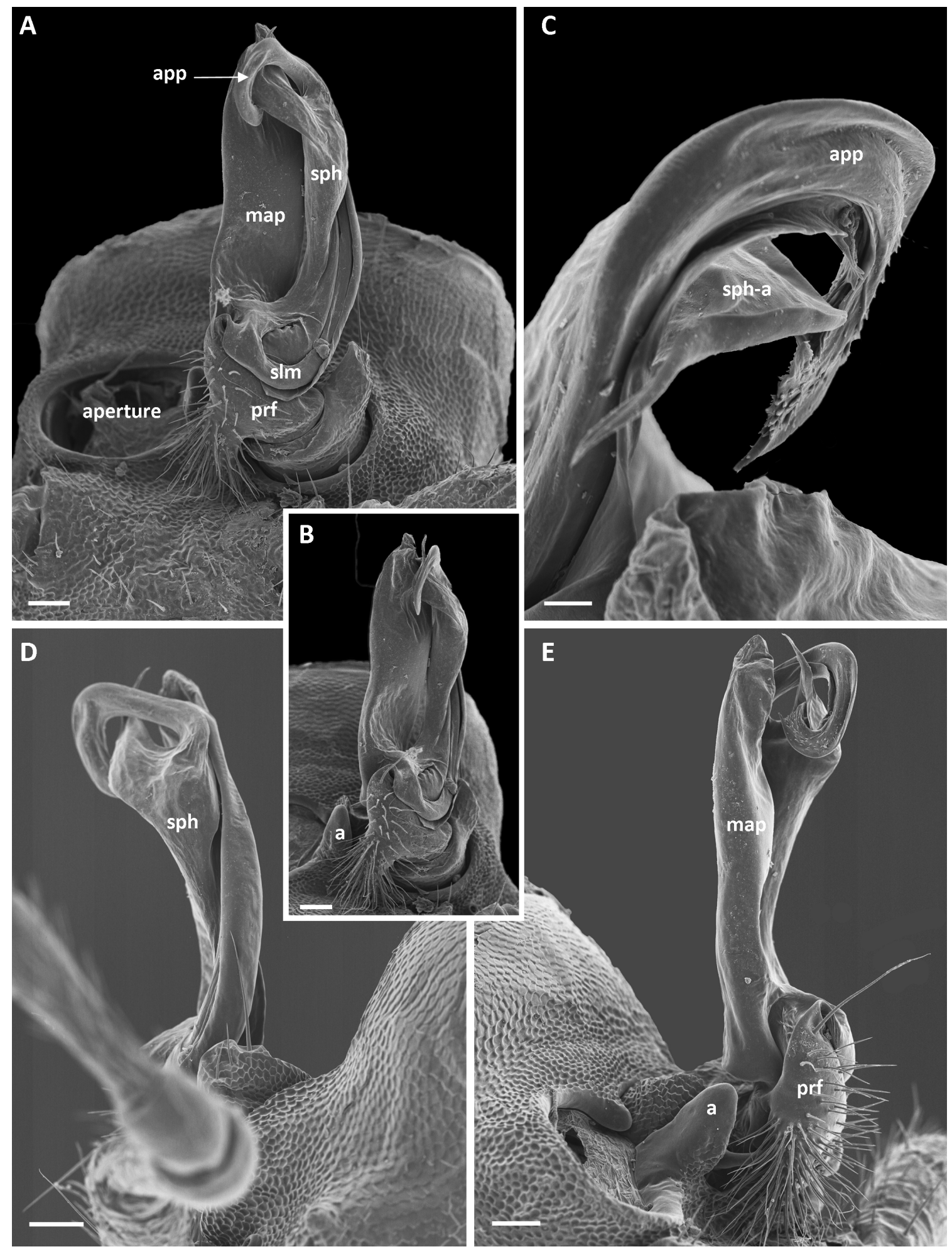

Fig. 4. Jeekelosoma abadi (Mauriès, 1985) comb. nov., male topotype (NHMD 302021), left gonopod in situ. A. Ventral view. B. Slightly meso-ventral view to show the keel a. C. Subapical view. D. Lateral view. E. Mesal view. Abbreviations: $a=$ posterior-median keel of gonopod aperture; $a p p=$ terminal appendage of solenophore; map = mesal acropodital process; $p r f=$ prefemoral part; $s l m=$ solenomere; $s p h=$ solenophore; sph- $a=$ apical lamella of solenophore. Scale bars: A-B, D-E $=0.05 \mathrm{~mm} ; \mathrm{C}=$ $0.01 \mathrm{~mm}$. 
Jeekelosoma heptarachne sp. nov.

urn:1sid:zoobank.org:act:F43040BD-C8DA-474A-94CD-A9FB3B9202C6

Figs 5-8

\section{Diagnosis}

A species of Jeekelosoma with 17 podous rings, with the ozopores borne on chimney-like outgrowths each provided with several macrosetae, with extremely long legs, and without a horizontal row of tubercles on podous rings 5-17.

\section{Etymology}

The name is a noun in apposition, composed of Greek 'hepta' (= seven) and 'arachne' (= spider). A male of the new species has 28 pairs of long, thin walking legs and thus (somewhat) resembles a row of seven spiders.

\section{Material examined}

\section{Holotype}

MOROCCO • đ’; Tazentout, cave Wit Tamdoun; 9 Aug. 1971; C. Ribera leg.; MZB 73-2849.

\section{Paratypes}

MOROCCO • 3 우; same collecting data data as for holotype; MZB 73-2849, MZB 71-8589, MZB 71-8590 • 1 \% ; in part mounted on two SEM stubs; MZB 71-8592 • 1 q; NHMD 302023.

\section{Description}

\section{Male}

Size. Body length ca $8 \mathrm{~mm}$, max. width $0.63 \mathrm{~mm}, 19$ 'segments' (17 podous rings +1 apodous ring + telson).

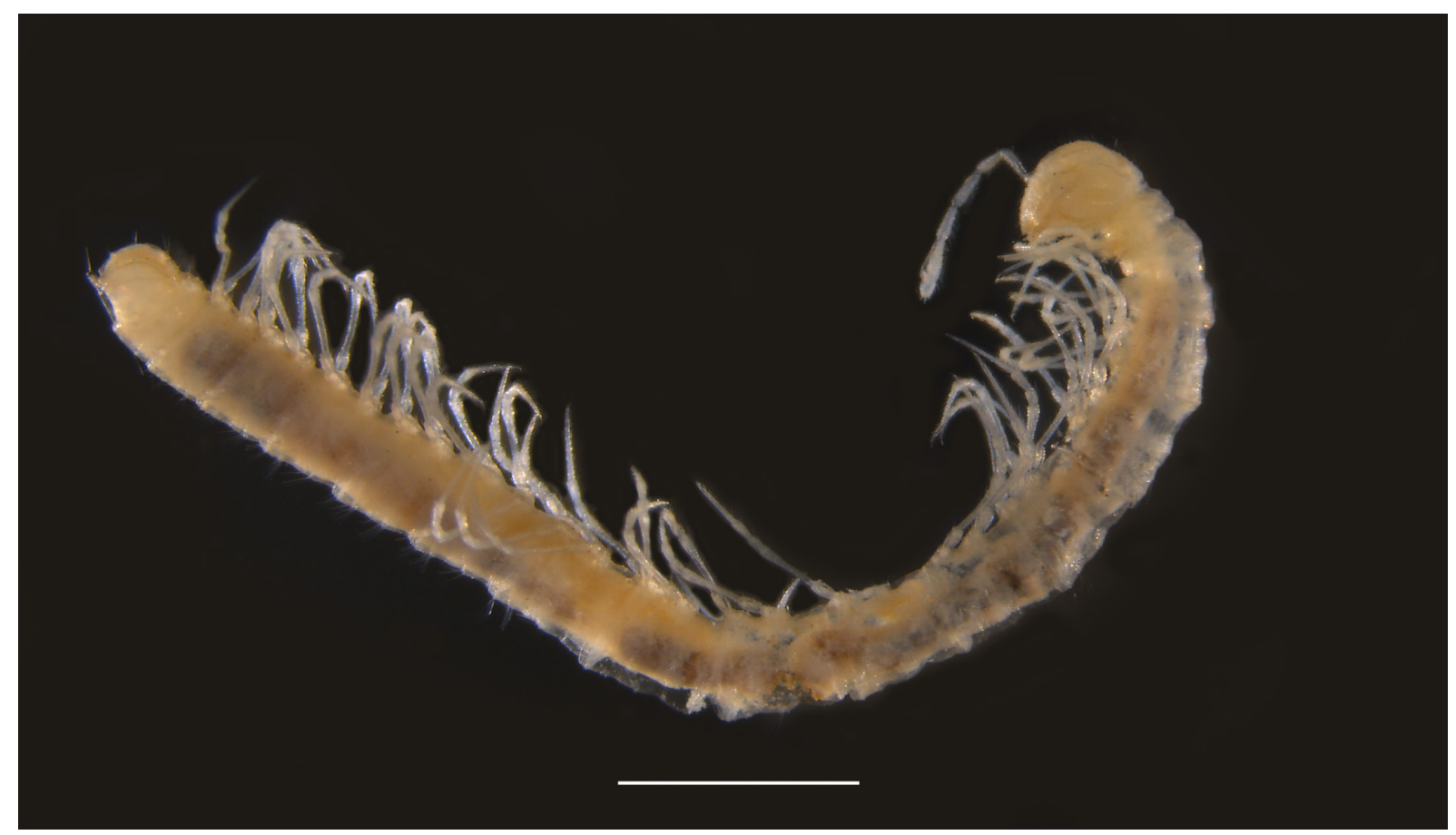

Fig. 5. Jeekelosoma heptarachne sp. nov., paratype, female (NHMD 302023). Scale bar $=1 \mathrm{~mm}$. 
HeAD. As in $J$. abadi, but densely covered by long setae. Length of antennae $3.1 \times$ max. body width. Relative length of antennomeres 2-8: 18 / 20/17/16/20/7/2.3.

Collum. As in J. abadi, but setae much longer.

MidBody Rings (Fig. 6A-C). Very narrow/elongated, length of metazona equaling maximum width. Body extremely narrow in anterior part, maximum width attained a little behind midbody; from there until and including ring 18 (the apodous ring in front of telson) body parallel-sided. Surface of metazona with very pronounced microcellulate structure, borders between cuticular scutes raised. Metazona with diameter increasing towards rear margin and with a clear constriction at ca $1 / 3$ of its length, measured from rear margin; posterior margin of rings finely crenulate but without a proper limbus. Each metazona with three rows of long, rather stout setae borne on distinct tubercles; each row on midbody rings with ca 10 setae; anterior row curving posteriad laterally; intermediate row situated just behind constriction. Metazonal setae much longer than in J. abadi (cf. Fig. 2). No horizontal row of tubercles, but lateral parts of anterior row appearing as oblique row of tubercles in lateral view.

OzOPOREs (Fig. 6G-H). On cylindrical peritremata, with 4-5 long, stout setae in a group anterodorsally to pore.

LEGS (Fig. 6C, E-F). Length $2.25 \times$ max. body width. Relative length of podomeres: prefemur: 12 / femur: 30 / postfemur: 7 / tibia: 11 / tarsus: 35 / claw: 2.4. Femora clearly longer than body diameter, no distal swelling. No scopulae.

Telson. As in J. abadi.

GONOPODAL APERTURE (Fig. 6D). Transverse elliptical, with a small median process originating on posterior margin.

GonOpods (Figs 7-8). Coxa ( $c x$ ) slightly convex on anterior surface; prefemoral part (prf) slightly more than half as long as acropodite; mesal acropodital process (map) a simple broad, dorso-ventrally flattened structure; solenophore $(s p h)$ as long as map, slender, apically with a subrectangular lamella $(s p h-a)$ with distal corners drawn out into long processes, but without a terminal appendage; solenomere $(\mathrm{slm})$ slender, simple, largely concealed within $s p h$.

\section{Female}

Non-sexual characters as in male, except:

Size. Body length $10-13 \mathrm{~mm}$, max. width $0.58-0.80 \mathrm{~mm}$.

ANTENNAE. Length in largest female $2.0 \times$ max. body width. Relative length of antennomeres 2-8: 18 / $18 / 16 / 16 / 21 / 7 / 3$.

LEGS. Length in largest female $1.8 \times$ max. body width. Relative length of podomeres: prefemur: 13 / femur: 32 / postfemur : 8 / tibia: 11 / tarsus: 34 / claw: 2.4 .

\section{Distribution and habitat}

Known only from "Tazentout, cave Wit Tamdoun". This cave (Bichain 2008) is also home to a rove beetle Domene cantonsi Español, 1972 known only from this and two further Moroccan caves (Hernando 2007), and to an endemic North African terrestrial isopod, Trichoniscus soloisensis Vandel, 1959 (Cruz 1991). 

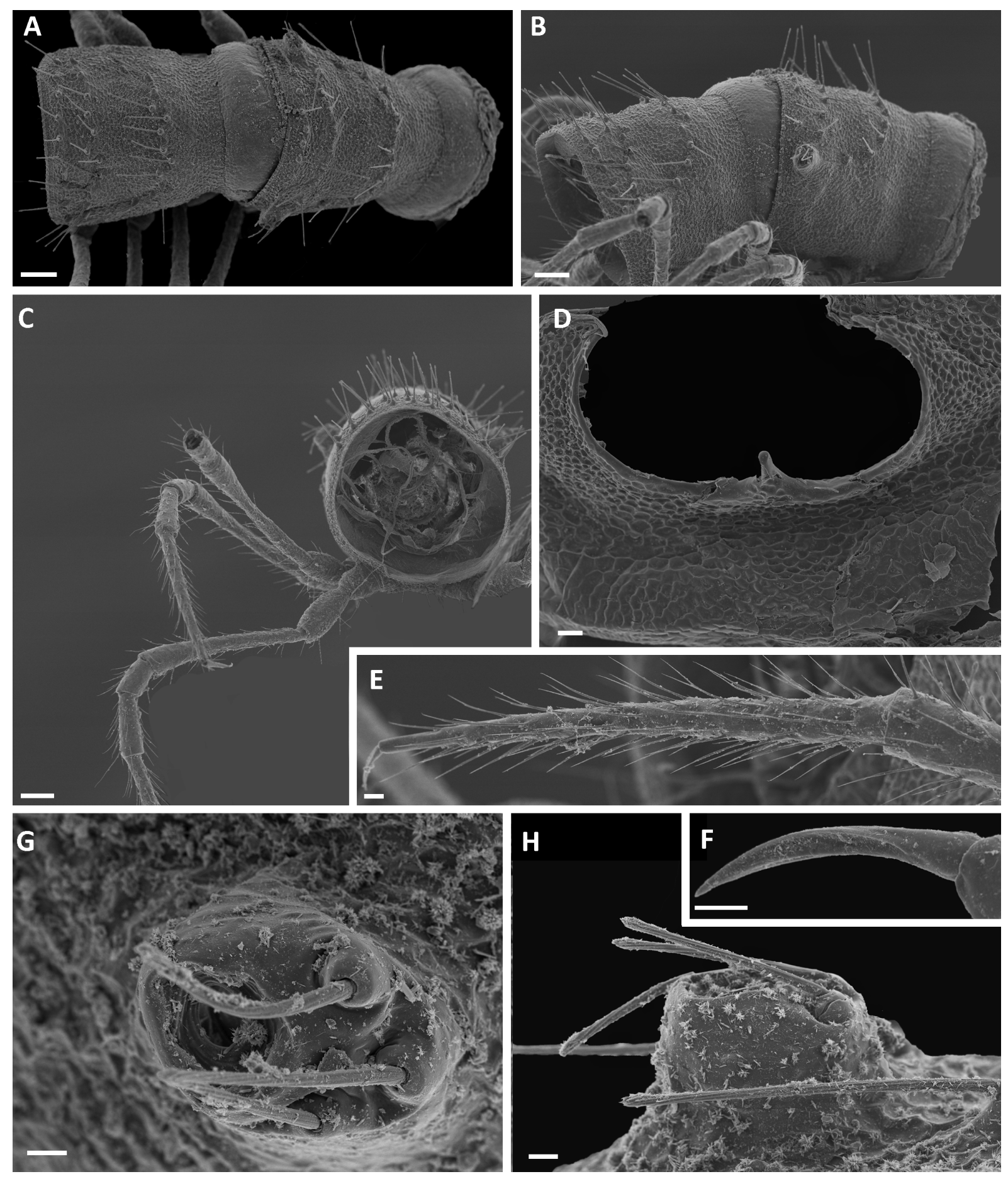

Fig. 6. Jeekelosoma heptarachne sp. nov., paratype, male (MZB 71-8589). A. Rings 10-11, dorsal view. B. Rings 10-11, lateral view. C. Rings 10-11, posterior view, with three legs of left side. D. gonopod aperture. E. Tarsus and claw of midbody leg. F. Claw of midbody leg. G-H. Right ozopore of ring 10. Scale bars: A-C $=0.1 \mathrm{~mm}$; D-E $=0.02 \mathrm{~mm}$; $-\mathrm{H}=0.01 \mathrm{~mm}$. 
ENGHOFF E. \& REBOLEIRA A.S.P.S., Jeekelosoma - Moroccan cave millipedes
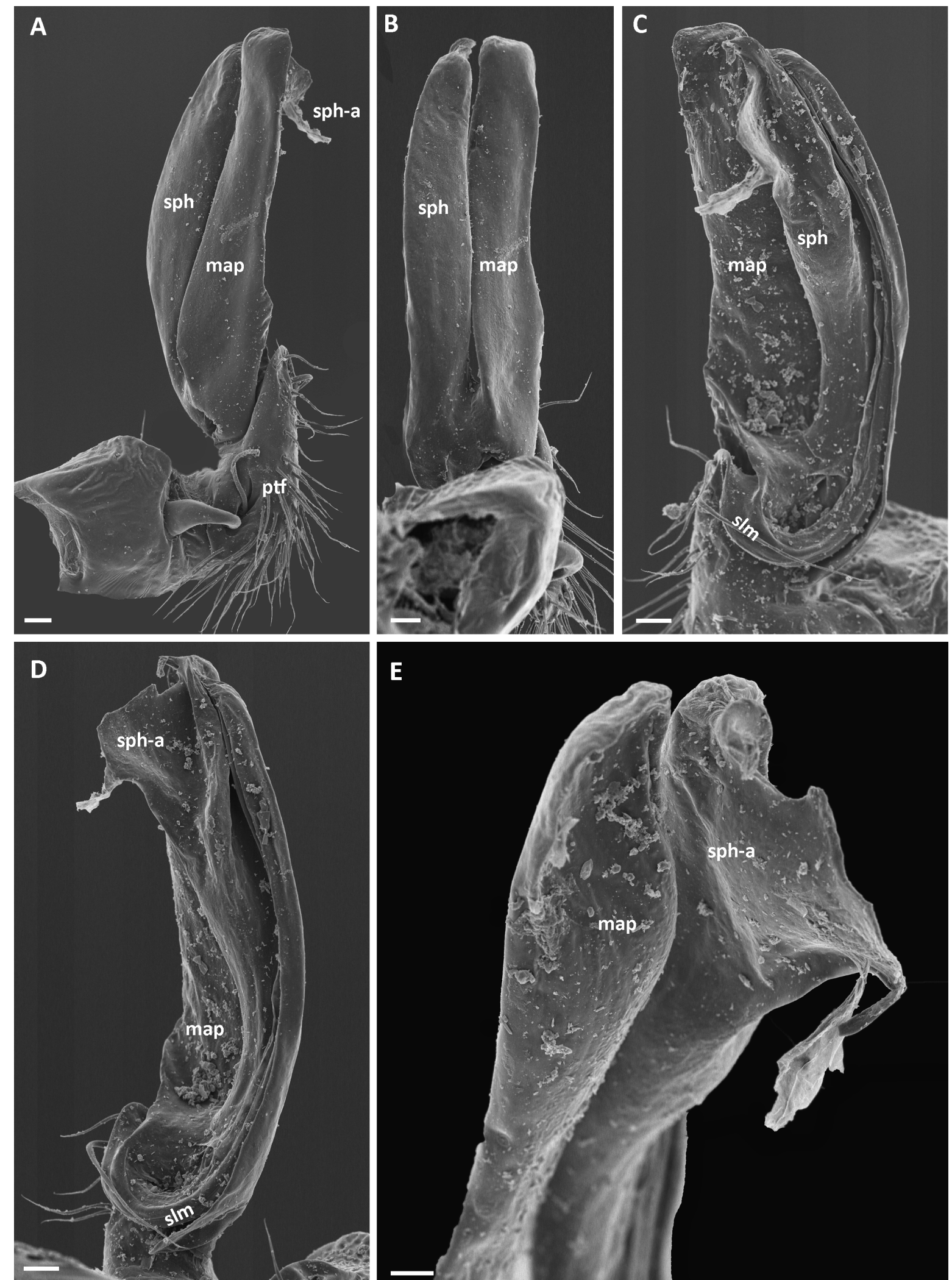

Fig. 7. Jeekelosoma heptarachne sp. nov., paratype, male (MZB 71-8589), left gonopod. A. Mesal view. B. Dorsal view. C. Ventral view. D. Lateral view. E. Gonopod tip, meso-ventral view. Abbreviations: $c x=$ coxa map $=$ mesal acropodital process; $p r f=$ prefemoral part; $s l m=$ solenomere; $s p h=$ solenophore; $s p h-a=$ apical lamella of solenophore. Scale bars: A-D $=0.02 \mathrm{~mm} ; \mathrm{E}=0.01 \mathrm{~mm}$. 


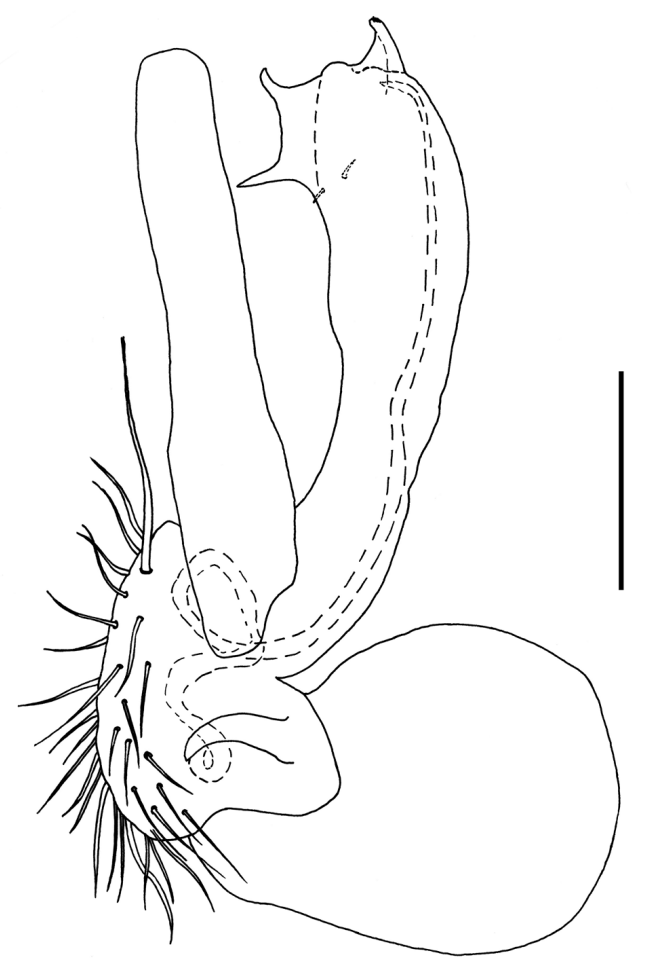

Fig. 8. Jeekelosoma heptarachne sp. nov., holotype, male (MZB 73-2849), left gonopod. Scale bar = $0.1 \mathrm{~mm}$.

\section{Jeekelosoma viginti sp. nov.}

urn:1sid:zoobank.org:act:49B57581-A5CF-41C9-A504-F05064F6287D

Fig. 9

\section{Diagnosis}

A species of Jeekelosoma with 18 podous rings, with the ozopores borne on mushroom-like outgrowths each provided with two macrosetae, and without a horizontal row of tubercles on podous rings 5-17.

\section{Etymology}

The name means 'twenty' in Latin and refers to the presence of 20 'segments' (18 podous rings +1 apodous ring + telson), vs 19 'rings' in the two other species.

\section{Material examined}

\section{Holotype}

MOROCCO - o; Kef Touna, Douar hayant, Ahermoumou, ca Ribat el Khayr; 21 May 2002; Fadrique-Escolà leg.; MZB 2003-0147.

\section{Paratypes}

MOROCCO • 1 q, 1 subad. đ̇; same collecting data as holotype; MZB 2003-0445, MZB 2019-0025 • 1 ㅇ same collecting data as holotype; NHMD 302024.

\section{Description}

\section{Male}

Unknown. 


\section{Female}

SizE. Body length $10.5-14.5 \mathrm{~mm}$, max. width $0.76-0.90 \mathrm{~mm}, 20$ 'segments' (18 podous rings +1 apodous ring + telson).

HEAD. As in J. abadi. Length of antennae $1.9 \times$ max. body width. Relative length of antennomeres 2-8: $17 / 20 / 17 / 15 / 18 / 9 / 3$.

Collum. As in J. abadi.

MidBody RINGS (Fig. 9A-B). Very narrow/elongated, length of metazona equaling ca $3 / 4$ of maximum width. Body extremely narrow in anterior part, maximum width attained a little behind midbody, from there until and including ring 19 (the apodous ring in front of telson) body parallel-sided. Surface of metazona with very pronounced microcellulate structure. Metazona with diameter increasing towards rear margin and with a clear constriction slightly behind middle; posterior margin of rings finely crenulate but without a proper limbus. Each metazona with three rows of long, rather stout setae borne on distinct tubercles; each row on midbody rings with ca 10 setae; anterior row curving posteriad laterally; intermediate row situated just behind constriction. Metazonal setae of moderate length, ca as in J. abadi, much shorter than in J. heptarachne. No horizontal row of tubercles at ozopore level, but lateral parts of anterior row appearing as oblique row of tubercles in lateral view.

OzOPOREs (Fig. 9C). On peculiar mushroom-like outgrowths (modified peritremata) as in J. abadi, but more oblong and pointed at anterior end; each 'mushroom' with one long seta behind pore and one in front.

LEGS (Fig. 9D-E). Length $1.6 \times$ max. body width. Relative length of podomeres: prefemur: 13 / femur: 32 / postfemur: 9 / tibia: 11 / tarsus: 30 / claw: 5 .

TELSON. As in J. abadi.

\section{Distribution and habitat}

Known only from the type locality which is also known as "Kef Tovna" and is located in a wide sinkhole near the village of Douar Tahyannt. It has served as a deposit of dead domestic animals. In the rainy season, which is usually very intense, the sinkhole is flooded, and the carcasses of cows, horses and other small animals are dragged into the cave, allowing the development of large quantities of allochthonous dipteran larvae (Fadrique pers. com.). No other cave-adapted species are known from this cave.

\section{Remarks}

It is usually inadvisable to describe a new species of chilognathan millipedes without having an adult male available. However, Jeekelsoma viginti sp. nov. is readily recognisable in the female sex, on the one hand sharing the peculiar non-sexual morphology of its known congeners and on the other hand being clearly different from both of them.

On the surface of one peritrema (Fig. 9F) rows of minute spherical structures were seen, resembling those described from various species of millipedes and regarded as being possibly of fungal nature by Enghoff \& Reboleira (2017).

\section{Discussion}

With Jeekelosoma now regarded as a full genus, the tribe Eviulisomatini contains seven genera, viz, Boreviulisoma Brolemann, 1928 (SW Palaearctic: NW Africa, SW Europe), Eviulisoma Silvestri, 1910 (Afrotropical), Jeekelosoma Mauriès, 1985 (SW Palaearctic: NW Africa), Onciurosoma Silvestri, 1932 
(Neotropical), Scolodesmus Cook, 1896 (Afrotropical), Suohelisoma Hoffman, 1964 (Afrotropical) and Wubidesmus Chamberlin, 1927 (Afrotropical).

Having the troglomorphic traits of depigmentation and very long legs, the species of Jeekelosoma can be regarded as troglobionts. As pointed out by Mauriès (1985) Jeekelosoma in this respect differs from Eviulisoma, the species of which are all epigean and non-troglomorphic. The only other troglobiont species of Eviulisomatini is Boreviulisoma barrocalense, described by Reboleira \& Enghoff (2013)

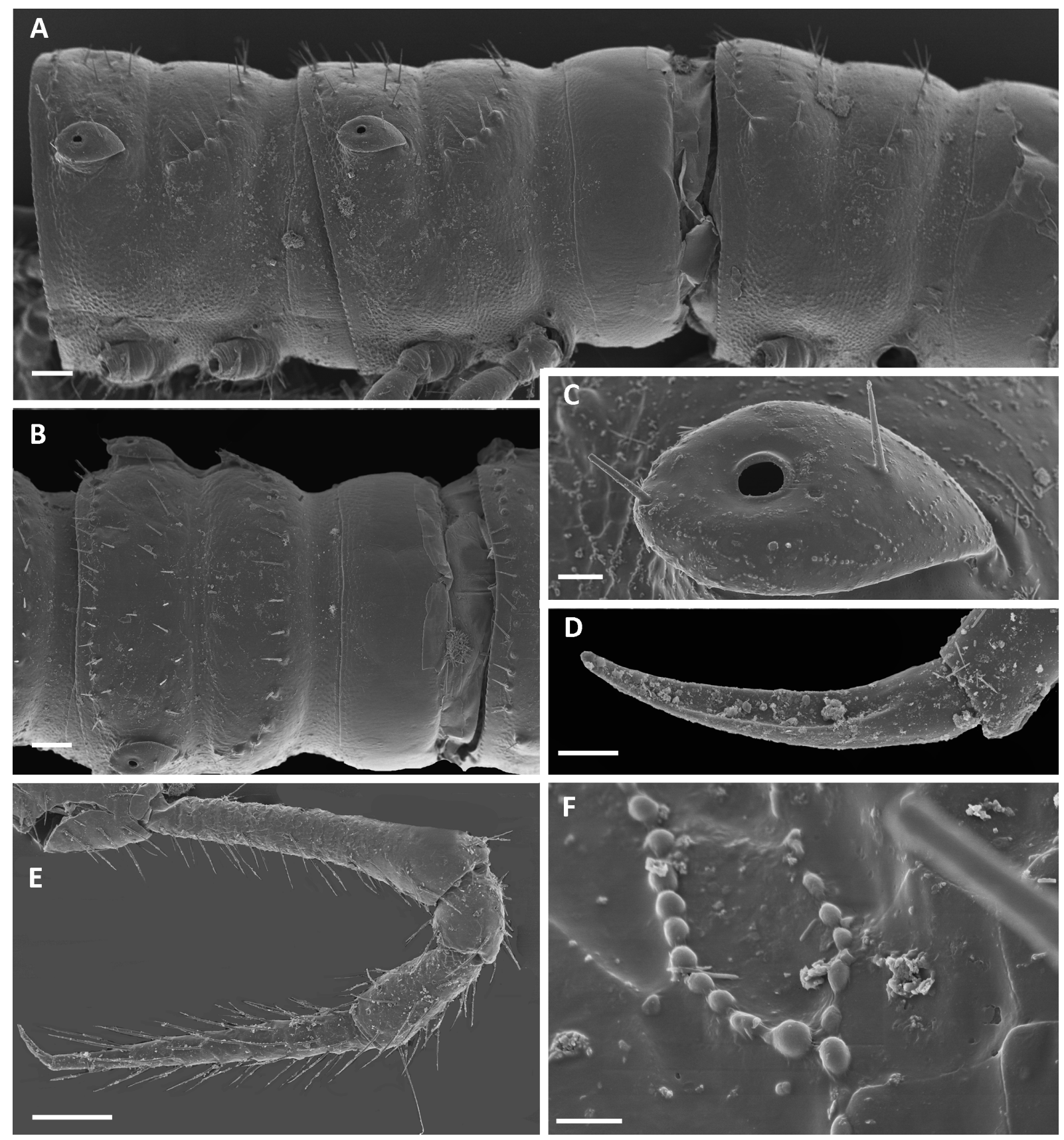

Fig. 9. Jeekelosoma viginti sp. nov. paratype female (NHMD 302024). A. Rings 8-10, lateral view. B. Ring 9, dorsal view. C. Right ozopore of ring 9. D. Claw of midbody leg. E. Midbody leg. F. Cuticular (fungal?) structures from surface of peritrema. Scale bars: A-B, E $=0.1 \mathrm{~mm} ; \mathrm{C}=0.02 \mathrm{~mm} ; \mathrm{D}=0.01 \mathrm{~mm}$; $\mathrm{F}=0.005 \mathrm{~mm}$. 
from southern Portugal. The monophyly of Eviulisomatini has not been supported by a phylogenetic analysis, but it may be noticed that the only eviulisomatinine genera containing troglobiont species are also the only ones which occur in the Palaearctic region.

The very long appendages, especially femora and tarsi of the walking legs seen in Jeekelosoma (Figs 2E, 6C, 9E), as compared to Eviulisoma (Enghoff 2018: figs 4, 7) are in line with the general tendency for troglomorphism in millipedes (Liu et al. 2017; see also Akkari et al. 2018).

\section{Acknowledgements}

We express our gratitude to Glòria Masó for giving us access to the Barcelona Museum Diplopoda collection and for loaning the type material, and to Floren Fadrique, Ignacio Ribera and Carles Hernando for kindly providing information and references on cave fauna from the type localities. ASR is supported by a research grant (15471) from VILLUM FONDEN.

\section{References}

Akkari N., Gilgado J.D., Ortuño V. \& Enghoff H. 2018. Out of the dark void: Ommatoiulus longicornis n. sp., a new julid from Spain (Julida, Diplopoda) with notes on troglobiomorphic traits in millipedes. Zootaxa 4420 (3): 415-429. https://doi.org/10.11646/zootaxa.4420.3.7

Antoine M. 1953. Présentation des Coleopteres troglobies. Comptes rendus mensuelles des Séances de la Société de Sciences Naturelles et Physiques du Maroc 19 (4): 58-59.

Barranco P. \& Mayoral J.G. 2007. A new species of Eukoenenia (Palpigradi, Eukoeneniidae) from Morocco. Journal of Arachnology 35 (2): 318-325. https://doi.org/10.1636/H05-23.1

Bichain J.-M. 2008. Win-Timdouine 2008: expédition spéléologique et biospéologique dans le plus grand réseau souterrain du continent africain (Maroc, Haut-Atlas, région d'Agadir). Muséum national d'Histoire naturelle de Paris, Muséum d'Histoire naturelle de Marrakech etc. http://wittamdoun.free.fr/documents/WT2008r_mai08.pdf

Cruz A. 1991. Isópodos terrestres de la colección del Museu de Zoologia de Barcelona (Crustacea, Oniscidea). Miscel·lània Zoològica 15: 81-102.

Enghoff H. 2018. A mountain of millipedes VII. The genus Eviulisoma Silvestri, 1910, in the Udzungwa Mountains, Tanzania, and related species from other Eastern Arc mountains. With notes on Eoseviulisoma Brolemann, 1920, and Suohelisoma Hoffman, 1963 (Diplopoda, Polydesmida, Paradoxosomatidae). European Journal of Taxonomy 445: 1-90. https://doi.org/10.5852/ejt.2018.445

Enghoff H., Golovatch S., Short M., Stoev P. \& Wesener T. 2015. Diplopoda - Taxonomic overview. In: Minelli A. (ed.) Treatise on Zoology - Anatomy, Taxonomy, Biology. The Myriapoda. 2: 363-453. Leiden, Boston. Brill. https://doi.org/10.1163/9789004188273_017

Enghoff H. \& Reboleira A.S.P.S. 2017. Diversity of non-Laboulbenialean fungi on millipedes. Studies in Fungi 2 (1): 130-137. https://www.doi.org/10.5943/sif/2/1/15

Español F. 1969. Un nuevo Apteranillus cavernícola de la régión de Boudenib, Marruecos presahariano (Col. Staphylinidae). Annales de Spéléologie 24 (1): 171-176.

Español F. 1972. Un nuevo Domene cavernicola de la region de Agadir, Marruecos Sud-Occidental (Col. Staphylinidae). Miscel·lània Zoològica 3 (2): 51-54.

Hernando C. 2007. Nuevos datos faunísticos y una nueva especie cavernícola de Domene Fauvel, 1885 subgénero Spelaeomene Español, 1977 de Marruecos (Coleoptera: Staphylinidae: Paederinae). Heteropterus Revista de Entomología 7 (1): 1-6.

Hoffman R.L. 1980. Classification of the Diplopoda. Muséum d'Histoire naturelle, Geneva. 
Jeekel C.A.W. 2003. African Paradoxosomatidae, 1: Genus Eviulisoma Silvestri (Diplopoda, Polydesmida). Myriapod Memoranda 6: 46-88.

Lagar A. 1978. Un nou Platyderus del Marroc (Coleoptera Pterostichidae). Excursionisme 41: 19-20.

Liu W., Golovatch S., Wesener T. \& Tian M. 2017. Convergent evolution of unique morphological adaptations to a subterranean environment in cave millipedes (Diplopoda). PLoS ONE 12 (2): e0170717. https://doi.org/10.1371/journal.pone.0170717

Luque C.G. \& Labrada L. 2017. Nuevas localizaciones de la especie Cantabrodesmus lorioli Mauriès, 1971 en Cantabria, España (Polydesmida, Diplopoda, Chelodesmidae). Boletin de la Real Sociedad Española de Historia natural Sección Biológica 111: 51-60.

Magniez G. 1977. Magniezia gardei n.sp. (Crustacea Isopoda Asellote): un Sténasellide des eaux souterraines du Maroc sud-oriental. International Journal of Speleology 9: 321-329.

Mauriès J.-P. 1971. Diplopodes épigés et cavernicoles des Pyrénées espagnoles et des Monts Cantabriques. VI. Polydesmides. Bulletin de la Société d'Histoire naturelle de Toulouse 107: 117-124.

Mauriès J.-P. 1974. Intérêt phylogénique et biogéographique de quelques Diplopodes récemment décrits du nord de l'Espagne. Symposia of the Zoological Society of London 32: 53-63.

Mauriès J.-P. 1985. Polydesmide et Craspedosomides nouveaux de France et du Maroc (Myriapoda Diplopoda). International Journal of Speleology 14: 51-62.

Nzoko Fiemapong A.R., Tamessee J.L. \& VandenSpiegel D. 2018. The first record of the millipede genus Eviulisoma Silvestri, 1910 (Diplopoda: Polydesmida: Paradoxosomatidae) in Cameroon, with descriptions of three new species. Arthropoda Selecta 27 (4): 278-282.

Reboleira A.S.P.S. \& Enghoff H. 2013. The genus Boreviulisoma Brolemann, 1928 - an Iberian-N African outlier of a mainly tropical tribe of millipedes (Diplopoda: Polydesmida: Paradoxosomatidae). Zootaxa 3646: 516-528. https://doi.org/10.11646/zootaxa.3646.5.2

Ribera C. 1993. Dysdera caeca n.sp. y Harpactea stalitoides n.sp. (Araneae), dos especies cavernícolas de Marruecos y Portugal. Revue arachnologique 10 (1): 1-7.

Stüben P.E. 2009. Neubeschreibungen westpaläarktischer Cryptorhynchinae III. (Torneuma, Echinodera, Acalles). Snudebiller 10: 94-106.

VandenSpiegel D. \& Golovatch S.I. 2014. The millipede genus Eviulisoma Silvestri, 1910 in Kenya, with descriptions of new species (Diplopoda, Polydesmida, Paradoxosomatidae). ZooKeys 459: 11-34. https://doi.org/10.3897/zookeys.459.8621

Manuscript received: 18 February 2019

Manuscript accepted: 15 March 2019

Published on: 7 May 2019

Topic editor: Rudy Jocqué

Desk editor: Radka Rosenbaumová

Printed versions of all papers are also deposited in the libraries of the institutes that are members of the EJT consortium: Muséum national d'Histoire naturelle, Paris, France; Meise Botanic Garden, Belgium; Royal Museum for Central Africa, Tervuren, Belgium; Royal Belgian Institute of Natural Sciences, Brussels, Belgium; Natural History Museum of Denmark, Copenhagen, Denmark; Naturalis Biodiversity Center, Leiden, the Netherlands; Museo Nacional de Ciencias Naturales-CSIC, Madrid, Spain; Real Jardín Botánico de Madrid CSIC, Spain; Zoological Research Museum Alexander Koenig, Bonn, Germany. 